\title{
Stratigraphic simulations of the shelf of the Gulf of Lions: testing subsidence rates and sea-level curves during the Pliocene and Quaternary
}

\author{
Estelle Leroux ${ }^{1,2,}$, Marina Rabineau ${ }^{1}$, Daniel Aslanian ${ }^{2}$, Didier Granjeon ${ }^{3}$, Laurence Droz ${ }^{1}$, \\ Christian Gorini ${ }^{4}$
}

\author{
${ }^{1}$ CNRS, UMR6538, Domaines Océaniques, IUEM, UBO, Plouzané, France \\ 2 IFREMER, Centre de Brest, GM, Plouzané, France \\ ${ }^{3}$ IFP-Energies Nouvelles, Rueil-Malmaison, France \\ ${ }^{4}$ UPMC, Univ. Paris 06, ISTEP, F-75005, Paris \\ *: Corresponding author : Estelle Leroux, tel.: +33682607163 ; email address : stll.leroux@gmail.com
}

\begin{abstract}
:
Determining the relative importance of factors interacting to control stratigraphic organization is a key issue in sedimentology. The Pliocene-Quaternary chronostratigraphy on the Gulf of Lions platform is still poorly constrained, giving rise to different interpretations of the evolution of its subsidence through time. This paper examines the Pliocene-Quaternary sedimentary filling of the Gulf of Lion's shelf with Dionisos, a numerical stratigraphic model. Our results show that a constant subsidence rate accurately reproduces the observed geometries, whereas a varying subsidence rate reproduces them only if the acceleration of subsidence is limited. At this time-scale, a third-order eustatic curve is also reappraised: a higher resolution curve (built using $\delta^{18} \mathrm{O}$ measurements) gives a more realistic restitution of our stratigraphic markers. Finally, the constant subsidence rate and sediment fluxes implied in these modellings are discussed relative to climate and local factors of sedimentation.
\end{abstract}




\section{INTRODUCTION}

\subsection{GEOLOGICAL SETTING}

The Gulf of Lions (Fig. 1) is an Upper Eocene passive margin, which results from the westward rotation of the CorsicaSardinia block and the simultaneous opening of a micro-ocean, the Liguro-Provençal basin (Montigny et al., 1981; LeDouaran et al., 1984; Réhault et al., 1984; Malinverno \& Ryan, 1986; Olivet, 1987; Gennesseaux et al., 1989; Gorini et. al, 1993; Mauffret et al., 1995; Olivet, 1996). This Western Mediterranean basin is a natural laboratory for climatic and stratigraphic researches because of its connection with the Atlantic Ocean (through the Gilbraltar Strait), its huge sedimentation and subsidence rates and its exceptionnal data set. Moreover its sedimentological record shows a very clear paleobathymetric and chronostratigraphic marker: the Messinian Margin Erosional Surface (MES) very well observed on the Liguro-Provençal margin (Savoye and Piper, 1991; Gorini et al., 1994; Guennoc et al., 2000; Lofi et al., 2005; Bache et al., 2009; Lofi et al., 2011). The closure of the Gibraltar Strait (Hodell et al., 1989; Krijgsman et al., 1999), associated with a strong evaporation rate (enhanced by a climate change) led to a drastic Mediterranean sea-level fall at the end of the Miocene (Barr and Walker, 1973; Chumakov, 1973; Clauzon, 1973; Hsü et al., 1973; Ryan, 1973), together with an intensive erosion of the margin. The MES, witness of this famous Messinian salinity crisis, has then been fossilized during the Zanclean transgression and high stand of sea-level. This MES surface constitutes the lowest marker of our study, in which we will try to quantify and/or point out factors affecting Plio-Quaternary sedimentation.

\subsection{DATA and EARLIER INTERPRETATION}

This work is based on the industrial seismic survey (LRM) realized in 1996 by Total and correlations with boreholes data. No detailed stratigraphic analyses have been performed on the Pliocene-Quaternary so that chronostratigraphic markers in this interval must be defined (Fig. 2).

The overall geometry of Pliocene-Quaternary strata shows prograding clinoforms (or prisms) with a clear geometrical change of the Late Pliocene to Quaternary clinoforms (after horizon p11, Fig. 2), from essentially prograding to prograding-aggrading. In more details, the comparison between earlier studies on Pliocene to Quaternary sedimentary record in the area shows similarities but also conflicting seismic interpretations (Fig. 3). Whilst the Zanclean/Piacenzian transition around 3.6-3.8 Ma is indeed picked out in the same way and at the same position by Rabineau et al. (2001), Lofi (2003) and Duvail et al. (2005) (blue p7 and red p6 horizons on the Fig. 3), these authors diverge about the stratigraphic position of the Pliocene/Pleistocene transition (2.6 Ma) (blue p11 and red p7 horizons on the Fig. 3). The exact position of the change between Pliocene prograding geometry and Pleistocene progradation-aggradation also varies with authors: the flat boundary horizon is identical in Rabineau 
(2001) and Duvail et al. (2005), but the sloping part of the horizon is much steeper in Duvail et al. (2005). On the other hand, according to the small amount of sediments, which would be accumulated after 3.8 Ma compared to that deposited in the lower Pliocene, Lofi (2003) suggests attributing an age younger than 2.7 Ma to a reflector slightly above blue horizon p11.

But the most significant difference is about the origin of the change from prograding to prograding-aggrading geometry, which has been explained by different scenarii concerning the Plio-Quaternary subsidence on the shelf. By measuring the topset slopes of the Plio-Quaternary prisms and the accomodation, Rabineau (2001) estimate a constant subsidence rate since 5.32 Ma (a seaward tilt of the margin reaching $255 \mathrm{~m} / \mathrm{My}$ at $70 \mathrm{~km}$ of the coast, with a rotation point at $13 \mathrm{~km}$ upstream the present day coastline), whereas the spatial organization of offlap-break led Duvail et al. (2005) to consider an increasing subsidence rate after his p6 marker (red in the Fig. 3) estimated at 2.6 Ma. Lofi et al. (2003) dit not estimate the subsidence.

The purpose of this study is to test this constant and some varying subsidence rates and constrain the above hypotheses by using numerical stratigraphic modelling.

\section{METHODS}

Sequence stratigraphic conceptual models (e.g. Catuneanu et al, 2009) are very helpful to analyze the sedimentary record, and decipher the relative role of key parameters such as accommodation and sediment supply. Stratigraphic forward numerical models have been developed since the early 1960s to test these conceptual frameworks and help understanding the role of each parameter on the overall stratigraphic architecture. Models intend to reproduce the dynamics of sedimentary systems.

Dionisos is a process-based modelling tool developed at IFP-Energies Nouvelles (Granjeon, 1997; Granjeon and Joseph, 1999) which successfully reproduced 2D and 3D overall geometry and lithology of a variety of siliciclatic case studies in coastal plain, littoral, deltaic, shoreface and offshore environments (Rabineau, 2001; Rabineau et al., 2005; Jouet, 2007; Csato et al., 2012) but also on the slope and the deep-sea environments (Euzen et al., 2004) and in carbonate environments (Burgess et al., 2006); it has also been used to test the impact of icehouse versus greenhouse related sea-level curves (Sømme et al., 2009).

Our purpose is to reproduce the last $5 \mathrm{Ma}$ geometry of strata and the position (in distance and depth) of the chronohorizons observed along the seismic profile LRM18 (Figs. 1,2) in different subsidence scenarii:

1) we first measure on the profile the horizontal position of the offlap-breaks of the major prisms. They are called p4, p7, p11, q10 and seafloor according to Rabineau (2001) (blue dots in the Fig. 3) and p3, p4, p5, p6, p7 according to Duvail et al. (2005) (red dots in the Fig. 3)

2) we create fictive wells in each of these positions (Fig. 4A) 
3) we calculate by iteration the sedimentary fluxes that give the best adjustment between the simulated and real (interpreted) offlap-breaks (Fig. 4)

In a second time, we tested the impact of two eustatic curves on respectively third- and fifth-order scales on the shelf morphology.

Details of Dionisos and input parameters quantification used in this study are described in supporting information.

\section{SIMULATION RESULTS}

\subsection{SUBSIDENCE}

The simulation using a constant rate of subsidence $(250 \mathrm{~m} / \mathrm{My})$ enables a good reproduction of prograding then progradingaggrading geometries (Fig. 4A). These geometrie are so linked to the fluxes and to the sea-level variations during the rebuilding of the shelf, after the Messinian Crisis. The simulations using non-constant subsidence rate fail to reproduce the clinoforms heights if the Pliocene subsidence is null or too small (Fig. 4B2-B3). The Pleistocene subsidence is then too strong and the height of final Pliocene clinoforms (which suffer the Pleistocene subsidence) is too small (even with higher Pliocene sediment fluxes). It means that a strong increase in subsidence (for the Quaternary) cannot restitute the clinoforms geometries. The only good restitution of the sedimentary record (Fig. 4-B1) is reached with the Pliocene (5.32 Ma-2.6 Ma) subsidence rate higher than $200 \mathrm{~m} / \mathrm{My}$, followed by a subsidence rate lower than $300 \mathrm{~m} / \mathrm{My}$. The maximal subsidence acceleration to allow a good reproduction of the geometry is therefore lower than $100 \mathrm{~m} / \mathrm{My}(50 \%)$.

On the other hand, smaller scale subsidence rates have also been tested independently using Upper Quaternary erosional surfaces over the last 450000 years and showed an average rate of subsidence on the outer shelf of $240 \mathrm{~m} / \mathrm{My}$ (Rabineau et al., 2005, 2006, 2007). This value has been confirmed by the ground-truth datation of sequences using the Promess-1 drilling site PRGL2 (Bassetti et al., 2008) and PRGL1 (Sierro et al., 2009).

\subsection{EUSTATISM}

The resolution of the sea-level curve used to run the stratigraphic model is an essential parameter for the modeling of the detailed spatial repartition of deposits, lithologies and erosional areas. Fig. 5 shows how the frequence and amplitude of eustatic cycles strongly influence the geometries of simulated deposits. In both cases, subsidence rate and sedimentary flux remain constant.

The first case (A) represents a simulation using the (Haq et al., 1987) sea-level curve. The offlap-break trajectory line appears segmented, with alternance of oceanwards and landwards movements (progradation/rétrogradation) following the five major 
128

eustatic cycles of the Haq's curve. At our time-scale, a third order eustatic curve, like Haq's curve, emphasizes large scale amplitudes of sea-level falls and rises, and favors erosion of prior transgessive system tracks during major regression. The simulation does not reproduce observed geometries (compare Figs. 5A and 2).

The second case (B), represents a simulation using a higher resolution sea-level curve resulting from $\partial^{18} \mathrm{O}$ data (Liesiecki and Raymo, 2005). The offlap-break trajectory appears more continuous with smaller shifts of the offlap-break due to weaker amplitudes of eustatic variations and a clearer prograding to a prograding-aggrading dynamic transition in good correlation with observed geometries (compare with Fig. 2). The high frequencies of $\delta^{18} \mathrm{O}$ data led to individualize more regressive/ transgressive cycles (and erosional surfaces) similar to those highlighted in the Quaternary (Aloïsi, 1986; Rabineau, 2001; Rabineau et al., 2005; Jouet, 2007) and confirmed by the recent Promess borehole (Bassetti et al., 2008).

\subsection{SEDIMENT FLUX AND WATER DISCHARGE}

The fluvial water discharge may be assumed as a function of climate (through precipitation and evaporation) and the size of the drainage area. The drainage area does not change in the simulation, the water discharge will then reflect primarily the climate (the main humidity trends).

Fig. 6 presents the sediment fluxes and water discharge given by simulations using the two tested sea-level curves. In both cases, Early Pliocene fluxes are relatively small (18-25 km³/My), whereas Late Pliocene and Quaternary fluxes are higher (95$100 \mathrm{~km}^{3} / \mathrm{My}$ ), which implies a considerable increase of sediment supply around 3.8 Ma. The water discharge evolves in the same way: after $3.8 \mathrm{Ma}$, a three fold increase is observed (from 100 to $300 \mathrm{~m}^{3} / \mathrm{s}$ ).

\section{DISCUSSION}

The evolution of water discharge is consistent with climate simulations for the Piacenzian interval of the late Pliocene indicating high precipitation in northwestern Europe (Jost et al., 2009).

Increase of sediment fluxes may be connected with the first cooling event at Zanclean / Piacenzian transition.The $\delta^{18} \mathrm{O}$ record on the last $5 \mathrm{Ma}$ indicates a step by step climatic deterioration which testifies the transition from a Messinian warm climate to a colder Pleistocene one (Shackleton et al.,1995; Lisiecki \& Raymo, 2005). Major cooling events existed since the Lower Pliocene, as attested by isotopic and palynologic signals (Suc et al., 1995; Popescu et al., 2010): Lower Pliocene is characterized by short-term and low amplitude temperature fluctuations. The first cooling event recorded around $3.5 \mathrm{Ma}$ corresponds to a global climate change due to the extension of continental ices in the Northern Hemisphere (Lear et al., 2000; Zachos et al., 2001). This event is also associated with extinction of planktonic foraminiferas (Rio et al., 1990) and the major sea-level fall named TB 3.4-3.5 cycle by Haq et al. (1987). This cooling episode may imply an increase of the terrigenous sedimentation in our basin by amplifying erosion on land. The increased and/or more efficient glacial erosion would bring 
160

161

162

163

164

165

166

167

168

169

170

171

172

173

174

175

176

177

more detrital material to rivers and basin. We can also suppose that drift ices trap important quantities of detrital particles, which are then discharged in the ocean (during the melt periods).

As Clauzon (1987) shown, the main part of Early Pliocene detrital sediments was trapped upstream from the shelf for the filling of the onshore Messinian incisions and the Gilbert-deltas construction. We infer that the Gilbert deltas have been first completely filled onshore, then allowing downstream delivery of sediments and the increase of the sediments fluxes in the shelf offshore. This is consistent with the well-known marine-continental transition and the Pliocene abandonment surface preceding the earliest glacial at 2.6 Ma observed on present-day onshore outcrops (Clauzon et al., 1995; Clauzon, 1996).

A second cooling event happened around 2.6 Ma. It follows the emergence of glacial/interglacial cycles in northern Hemisphere since 3.0 Ma-3.2 Ma (Shackleton et al., 1995; Zachos et al., 2001) with an increase of floating ices in North Atlantic (Backman, 1979). Faster climatic variations and higher frequency relative sea-level fluctuations occured after that period. A worldwide transition, called the "Mid Pleistocene Revolution", took place at Early to Mid Pleistocene. That transition reflects a fundamental change in terrestrial climatic cyclicity: the yet overwhelming obliquity (41 ka cycles) is progressively supplanted by greater amplitudes cycles (100 ka cycles). This change is dated around 0.8-0.9 Ma, and came along a worldwide ice-volume growth (Head and Gibbard, 2005). Contrarily to the first major cooling at 3.8 Ma, these last climatic events do not modify the detritical budget in our study area. However we must highlight that our simulations were restricted to the shelf and we suggest that an important part of the sediments has been discharged to the slope and the deep basin after 3.8 Ma and more specifically after $1 \mathrm{Ma}$. Futher modellings integrating the deep basin are necessary to generalize these partial observations and establish consistent source-to-sink sedimentary budgets.

\section{CONCLUSIONS}

Stratigraphic simulations enabled us to test different hypotheses on subsidence rates and sea-level variations.

First, the simulation using a subsidence taking the form of a tilt but with a constant subsidence rate trough time $(250 \mathrm{~m} / \mathrm{My}$ at $70 \mathrm{~km}$ from the coast for the entire Pliocene-Quaternary) offers a good restitution of clinoform geometries with a change from an Early Pliocene essentially prograding to a Pleistocene prograding-aggrading pattern. Simulated geometries obtained with a variable rate of subsidence are realistic only if the acceleration of subsidence after $2.6 \mathrm{Ma}$ is reduced (from $200 \mathrm{~m} / \mathrm{My}$ to 300 $\mathrm{m} / \mathrm{My}$ ). Simulation with important increase in subsidence rate through time could not fit the observed geometries and the constant (or almost constant) subsidence is therefore confirmed by our study.

Furthermore, the simulation with a high resolution sea-level curve led to more detailed clinoform restitution than a third order sea-level curve (Haq et al., 1987).

Finally, simulations showed an increase of sediment supply around 3.8 Ma on the shelf. It might be related to the beginning of a global climate cooling in the Northern Hemisphere or to the end of the upstream trapping of the sediments into the Gilbert Deltas in relation with the Messinian Salinity Crisis. 
Acknowledgements:

Stratigraphic simulations were performed with IFP-Energies Nouvelles Dionisos software kindly made available to the

University of Brest. We would like to thanks Audrey Gailler which has helped us to use the velocity model. This research was mainly funded by CNRS and IFREMER, with additional support from the French Actions-Marges and CNRS-INSU SYSTER program (EROGOL). This work also benefited from the Labex Mer initiative, a State Grant from the French Agence Nationale de la Recherche (ANR) in the Program «Investissements d'avenir » with the reference ANR-10-LABX-19-01, Labex Mer.

\section{REFERENCES:}

Aloïsi, J.C., 1986. Sur un modèle de sédimentation deltaïque: contribution à la connaissance des marges passives. PhD thesis, University of Perpignan, 162 p.

Backman, J., 1979. Pliocene biostratigraphy of DSDP Sites 111 and 116 from the North Atlantic Ocean and the age of the Northern Hemisphere Glaciation. Stockl. Contr. Geol., 32, 115-137.

Barr, F., and Walker, B., 1973. Late Tertiary channel system in northern Libya and its implications on Mediterranean sea level changes. In: Initial Reports of Deep Sea Drilling Project, W.B.F. Ryan and K.J. Hsü (Eds.), U.S. Government Printing Office, Washington, D.C., 13, Part 2, 1244-1250. Assoc. of Petr. Geol. Bulletin, 90, 1883-1901.

Burgess, P.M., Lammers, H., van Oosterhout, C. and Granjeon, D., 2006. Multivariate sequence stratigraphy: Tackling complexity and uncertainty with stratigraphic forward modeling, multiple scenarios, and conditional frequency maps. Am.

Catuneanu, O, Abreu, V., Bhattacharya, J.P., Blum, M.D., Dalrymple, R.W., Eriksson, P.G., Fielding, C.R., Fisher, W.L., Galloway, W.E., Gibling, M.R., Giles, K.A., Holbrook, J.M., Jordan, R., Kendall, C.G.St.C., Macurda, B., Martinsen, O.J., Miall, A.D., Neal, J.E, Nummedal, D., Pomar, L., Posamentier, H.W., Pratt, B.R., Sarg, J.F., Shanley, K.W., Steel, R.J., Strasser, A., Tucker, M.E. and Winker, C., 2009. Towards the standardization of sequence stratigraphy. Earth-Sci. Rev., 92 (12), 1-33.

Chumakov, I., 1973. Pliocene and pleistocene deposits of the nile valley in nubia and upper egypt., In: Initial Report of Deep Sea Drilling Project, W.B.F. Ryan, K.J. Hsü and al.(Eds), U.S. Government Printing Office, Washington, D.C., 13, 1242- 
Clauzon, G., 1973. The eustatic hypothesis and the pre-pliocene cutting of the rhône valley. In: Initial Report of the Deep Sea

Clauzon, G., 1987. Neogene geodynamical evolution of a pyreneo-mediterranean graben: the roussillon example (southern france). In: Proceedings of the VIIIth Congress of the Regional Committee on Mediterranean Neogene Stratigraphy (D.

Clauzon, G., 1996. Limites de séquences et évolution géodynamique. Géomorphologie, 1, 3-22.

Clauzon, G., Rubino, J.-L., Suc, J.-P., 1996. Les rias pliocènes du Var et de Ligure: comblement sédimentaire et évolution géodynamique. Livret-guide de l'excursion commune du Groupe Français d'Etude du Néogène et du Groupe Français de Géomorphologie, 6 au 8 septembre 1996, 111 p.

Csato, I., Granjeon, D., Catuneanu, O. and Baum, G.R., 2012. A three dimensional stratigraphic model for the Messinian crisis in the Pannonian Basin, eastern Hungary. Basin Research, 0, 1-28.

Duvail, C., Gorini, C., Lofi, J., Strat, P.L., Clauzon, G. and Reis, A.D., 2005. Corrélation between onshore and offshore pliocene-quaternary system tracts below the roussillon basin (Eastern Pyrenees, France). Mar. Petrol. Geol., 22, 747-756. 
258

259

260

261

262

263

264

265

266

267

268

269

270

271

272

273

274

275

276

277

Fairbanks, R.G. and Matthews, R.K., 1978. The oxygen isotope stratigraphy of the Plesitocene reef tracts of Barbados, West Indies. Quaternary Research, 10 (1), 181-196.

Gennesseaux, M., Rehault, J. and Thomas, B., 1989. La marge continentale de la corse, Bulletin de la Société Géologique de France, 5, 339- 351.

Gorini, C., 1993. Géodynamique d'une marge passive: le golfe du lion (méditerranée occidentale). PhD thesis, University of Paul Sabatier, Toulouse, $256 \mathrm{p}$.

Gorini, C., Mauffret, A., Guennoc, P. and Marrec, A. L., 1994. Structure of the gulf of lions (northwest mediterranean sea): A review. In: Hydrocarbon and petroleum geology of France, A. Mascle (Ed), Special Publication of the European Association of Petroleum Geology, Springer-Verlag, Berlin, 4, 223-243.

Granjeon, D., 1997. Modélisation stratigraphique déterministe: conception et applications d'un modèle diffusif 3d Multilithologique. PhD thesis, University of Rennes 1.

Granjeon, D. and Joseph P., 1999. Concepts and applications of a 3-d multiple lithology, diffusive model in stratigraphic modelling. In: Numerical Experiments in Stratigraphy: Recent Advances in Stratigraphic and Sedimentologic Computer Simulation, SEPM Spec. Pub. 62, Tulsa, 197-210.

Guennoc, P., Gorini, C. and Mauffret A., 2000. Histoire géologique du golfe du lion et cartographie du rift oligo-aquitanien et de la surface d'érosion messinienne. Géologie de la France, 3, 67-97.

Haq, B., Hardenbol, J. and Vail P., 1987. Chronology of fluctuating sea levels since the triassic (250 million years ago to present), Science, 235, 1156-1166.

Head, M. and Gibbard, P., 2005. Early-middle pleistocene transitions : the land-ocean evidence. Geological Society, London, Spec. Pub., 247.

Hodell, D., Benson, R., Kennett, J. and. El Bied, K. R, 1989. Stable isotope stratigraphy of latest miocene sequences in northwest morocco: the Bou Regreg section. Paleoceanography, 4(4), 467-482.

Hsü, K., Cita, M. and Ryan, W., 1973. The origine of the Mediterranean evaporites. In: Initial Report of the Deep Sea Drilling 
Project 13, W.B.F. Ryan, K.J. Hsü and al. (Eds), U.S. Government Printing Office, Washington, 1203-1231.

Jost, A., Fauquette, S., Kageyama, M., Krinner, G., Ramstein, G., Sue, J.P. and Violette, S., 2009. High resolution climate and

Climate of the past, 5(4), 585-606.

Jouet, G., 2007. Enregistrements stratigraphiques des cycles climatiques et glacio-eustatiques du quaternaire terminal. PhD thesis, University of Bretagne Occidentale. http:www.ifremer.fr/docelec

Krijgsman, W., Hilgen, F., Raffi, I., Sierro, F. and Wilson, D., 1999b. Chronology, causes and progression of the messinian salinity crisis. Nature, 400(12), 652-655.

302

Lear, C., Elderfield H. and Wilson P., 2000. Cenozoic deep-sea temperatures from mg/ca in benthic foraminiferal calcite. Science, 287, 269-272.

LeDouaran, S., Burrus, J. and Avedik, F., 1984. Deep structure of the north-west mediterranean basin: results of two-ship seismic survey. Mar. Geol., 55, 325-345.

Leroux, E., 2008. Simulations stratigraphiques des dépôts plio-quaternaires de la plate-forme du golfe du lion, Mémoire de stade de Master2, Géosciences Marines de l’Université de Bretagne Occidentale.

Leroux, E., 2012. Quantification des flux sédimentaires et de la subsidence du bassin Provençal, PhD thesis, University of Bretagne Occidentale, Brest, 455p., http://www.ifremer.fr/docelec or http://www.archives-ouvertes.fr

Lofi, J., 2002. La crise de salinité messinienne : conséquences directes et différées sur l'évolution sédimentaire de la marge du golfe du lion, $\mathrm{PhD}$ thesis, University of Sciences et Technics of Lille I, Lille, $261 \mathrm{p}$. 
Malinverno, A. and Ryan, W., 1986. Extension in tyrrhenian sea and shortening in the apennines as result of arc migration driven by sinking of the lithosphere. Tectonophysics, 5, 227-254.

Mauffret, A., Pascal, G., Maillard, A. and Gorini, C., 1995. Tectonics and deep structure of the North-Western Mediterranean basin. Mar. Pet. Geol., 12(6), 645-646.

Montigny, R., Edel, J. and Thuizat, R., 1981. Oligo-miocene rotation of sardinia: K-ar ages and paleomagnetism data of tertiary volcanics. Earth Planet. Sci. Lett., 54, 261-271.

Olivet, J.-L., 1987. L’origine du bassin nord-occidental de la méditerranée du point de vue de la cinématique des plaques. In : Profils ECORS. Golfe du Lion: Rapport d'implantation, J. Burrus and J-L. Olivet (Eds), IFP, Paris, 35 941-1, 10-49.

Olivet, J.-L., 1996. La cinématique de la plaque ibérique. Bulletin du Centre de Recherche et d'Exploration, Production Elf Aquitaine, 20, 131-195.

Réhault, J.-P., Boillot, G. and Mauffret, A., 1984. The western mediterranean basin, geological evolution. Mar. Geol., 55, 447-

Popescu, S., Biltekin, D., Winter, H., Suc, J-P., Melinte-Dobrinescu, MC, Rabineau M. and Clauzon, G., 2010. Pliocene and Early-Middle Pleistocene vegetation and climate changes at the European scale: long pollen records and climatostratigraphy. Quaternary International, 219(1-2), 152-167.

Rabineau, M., 2001. Un modèle géométrique et stratigraphique des séquences de dépôs quaternaires de la plate-forme du golfe du lion: enregistrement des cycles glacioeustatiques de 100 000ans. PhD thesis, University of Rennes 1/ IFREMER. http:www.ifremer.fr/docelec

Rabineau, M., Berné, S., Aslanian, D., Olivet, J.-L., Joseph, P., Guillocheau, F., Bourrillet, J.-L., Ledrezen, E. and Granjeon, D., 2005. Sedimentary sequences in the Gulf of Lions: a record of 100,000 years climatic cycles. Mar. Pet. Geol., 22, $775-804$. 477.

Rio, D., Sprovieri, R., Thunell, R., Grazzini, C.V. and Glacon, G., 1990. Pliocene-Pleistocene paleoenvironmental history of the Western Mediterranean: a synthesis of ODP site 653 results. In: Proceedings of the Ocean Drilling Program, Scientific Results, K.A. Kastens, J. Mascle et al. (Eds), 107. 
Ryan, W., 1973. Geodynamic implications of the messinian crisis of salinity. In: C.W. Drooger (Ed.), Messinian Events in Mediterranean, North-Holland Publ. Co., Amsterdam, Netherland, 26-38.

360

Savoye, B. and Piper, D., 1991. The messinian event on the margin of the mediterranean sea in the nice area, southern France.

Shackleton, N., 1987. Oxygen isotopes, ice volume and sea level. Quaternary Science Reviews, 6 (3-4), 183-190.

Shackleton, N., Hall, M. and Pate, D., 1995. Pliocene stable isotope stratigraphy of site 846. Proceedings of the Ocean Drilling Program, Scientific Results, 138, 337-355.

Somme, T.O., Helland-Hansen, W., Granjeon, D., 2009. Impact of eustatic amplitude variations on shelf morphology, sediment dispersal, and sequence stratigraphic interpretation: Icehouse versus greenhouse systems. Geology, 37(7), 587-590.

Suc, J.P., Bertini, A, Combourrieu-Nebout, N., Diniz, F., Leroy, S., Russo-Ermolli, E., Zheng, Z., Bessais, E. and Ferrier, J., 1995. Structure of west mediterranean vegetation and climate since 5.3My. Acta Zool. Cracoviensia, 38, 3-16.

Waelbroeck, C., Labeyrie, L., Michel, E., Duplessy, J., McManus, J., Lambeck, K., Balbon, E. and Labracherie M., 2002. Sealevel and deep water temperature changes derived from benthic foraminifera isotopic records. Quaternary Science Reviews, 21 (1-3), 295-305. 
Figure 1. Location of the study area and dataset on the bathymetric map of the Gulf of Lions. Red line: LRM18 seismic profile used in this study; black triangles: petroleum wells.

Figure 2. Interpretated LRM18 seismic reflection profile. The offlap-breaks are located with white dots; the first Pliocene prism (p1) is also hightlighted (yellow). Inset: the overall geometry of Pliocene-Quaternary strata shows prograding clinoforms (or prisms) with a clear geometrical change of the Late Pliocene to Quaternary clinoforms (after yellow horizon p11), from essentially prograding (dark green) to prograding-aggrading (light green).

Figure 3. Synthesis of LRM18 seismic interpretations on the shelf of the Gulf of Lions by different authors. Interpretation from Rabineau (2001) in blue; interpretation from Lofi (2002) and Lofi et al. (2003) in green; interpretation from Duvail et al. (2005) and Duvail (2008) in red. The interpreted chronostratigraphic markers have been digitalized, time-depth converted and superimposed on the same vertical section with respective age estimates.

Figure 4. Simulations testing subsidence rates with a 100000 years time-step (modified from Leroux, 2008). Comparaison of LRM18 seismic profile interpretations (grey lines) with simulated geometries and deposits bathymetry predicted by Dionisos (thick coloured lines). The simulations are run with a third order sea-level curve (Haq et al., 1988). A) Simulation with a constant subsidence rate of $250 \mathrm{~m} / \mathrm{My}$ at $70 \mathrm{~km}$ from the coast, then B1), B2), B3) using increasing subsidence rates. Note that the change to overall prograding-aggrading pattern occurs without any change in the subsidence rate. Note that we could not restitute the observations in B2 nor B3 when the increase of subsidence is too strong or with no subsidence between 5.3 Ma and 2.6 Ma. Note also that in both cases, the observed height for the Early Pliocene clinoforms could not be reproduced. Once the horizontal positions of the offlap-breaks along seismic profile have been adjusted, their simulated depths are too deep (see the highlighted yellow area on the right). In such a subsidence scenario, the accommodation which is created after 2.6 Ma increases too much the topsets slopes of the clinoforms already deposited. Note on the fictive wells that sand is deposited at the shelf-break, whereas finer sediments (silt and shale) are deposited on the shelf and on the slope (with a downstream decreasing granulometry).

Figure 5 - Simulations testing sea-level curves 
422 Comparison of simulated geometries (modified from Leroux, 2008) using (A) Haq et al. (1987) sea-level curve and (B) a

423 higher resolution sea-level curve resulting from $\partial^{18} \mathrm{O}$ data (Lisiecki and Raymo, 2005).

424 Simulations are running with a 10000 y time-step. All the others input parameters are identical in the both simulations (with 425 constant $45 \mathrm{~km}^{3} / \mathrm{My}$ sedimentary flux and $250 \mathrm{~m} / \mathrm{My}$ subsidence rate on the time interval). The chronomarkers correspond to the major sea-level falls (red) or to the Maximum Flooding Surface/MFS (blue). Black circles show offlap-break positions.

Figure 6. Evolution of the required sediment fluxes in our modellings in the case of a constant Plio-Quaternary subsidence rate. These fluxes result from 10000 years time step simulations with (A) third order eustatic curve (Haq et al., 1988) and (B) 

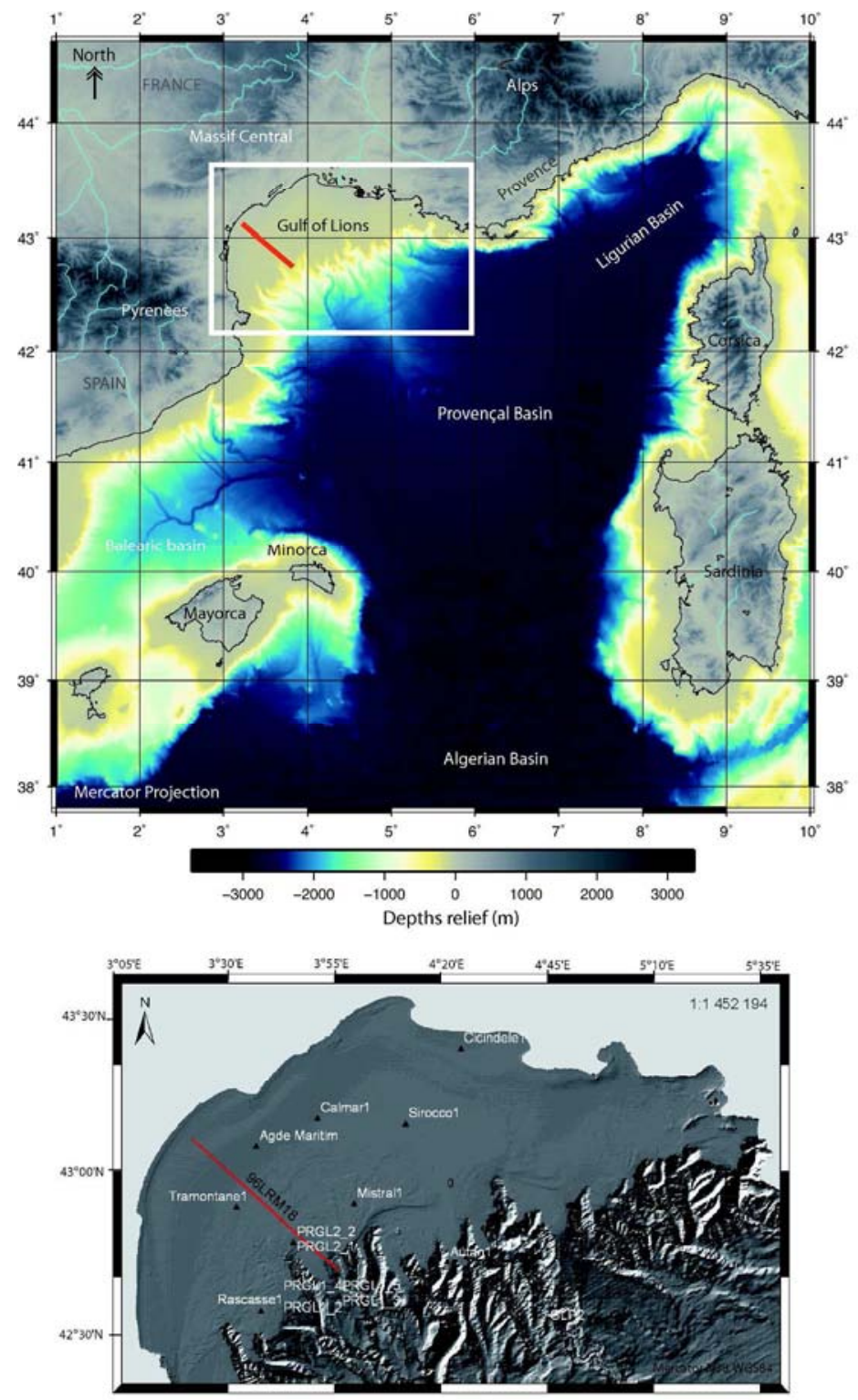

Leroux et al., Figure 1

Figure 1. Location of the study area and dataset on the bathymetric map of the Gulf of Lions. Red line: LRM18 seismic profile used in this study; black triangles: petroleum wells. $204 \times 342 \mathrm{~mm}(300 \times 300$ DPI) 


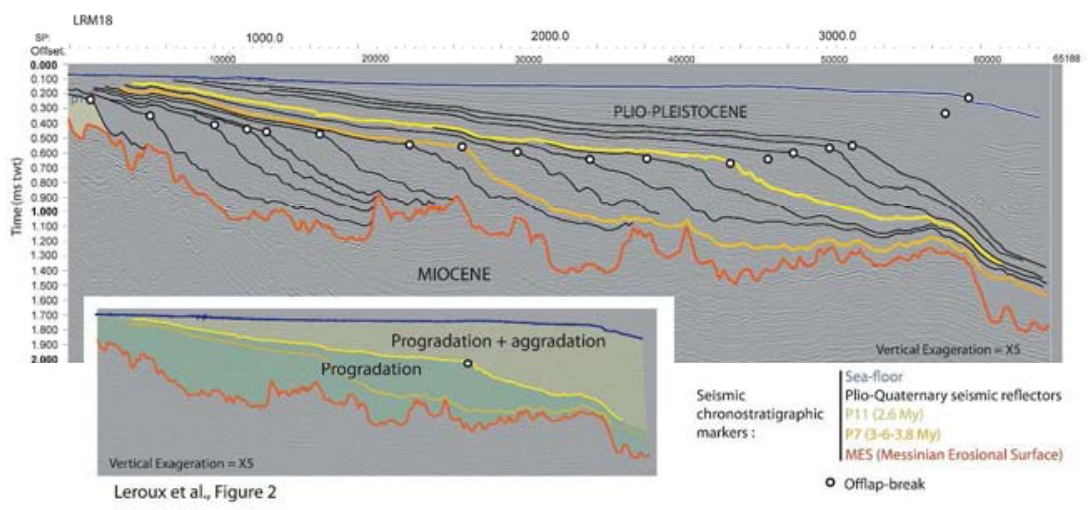

Figure 2. Interpretated LRM18 seismic reflection profile. The offlap-breaks are located with white dots; the first Pliocene prism ( $p 1$ ) is also hightlighted (yellow). Inset: the overall geometry of Pliocene-Quaternary strata shows prograding clinoforms (or prisms) with a clear geometrical change of the Late Pliocene to Quaternary clinoforms (after yellow horizon p11), from essentially prograding (dark green) to progradingaggrading (light green).

297x420mm (300 x 300 DPI) 


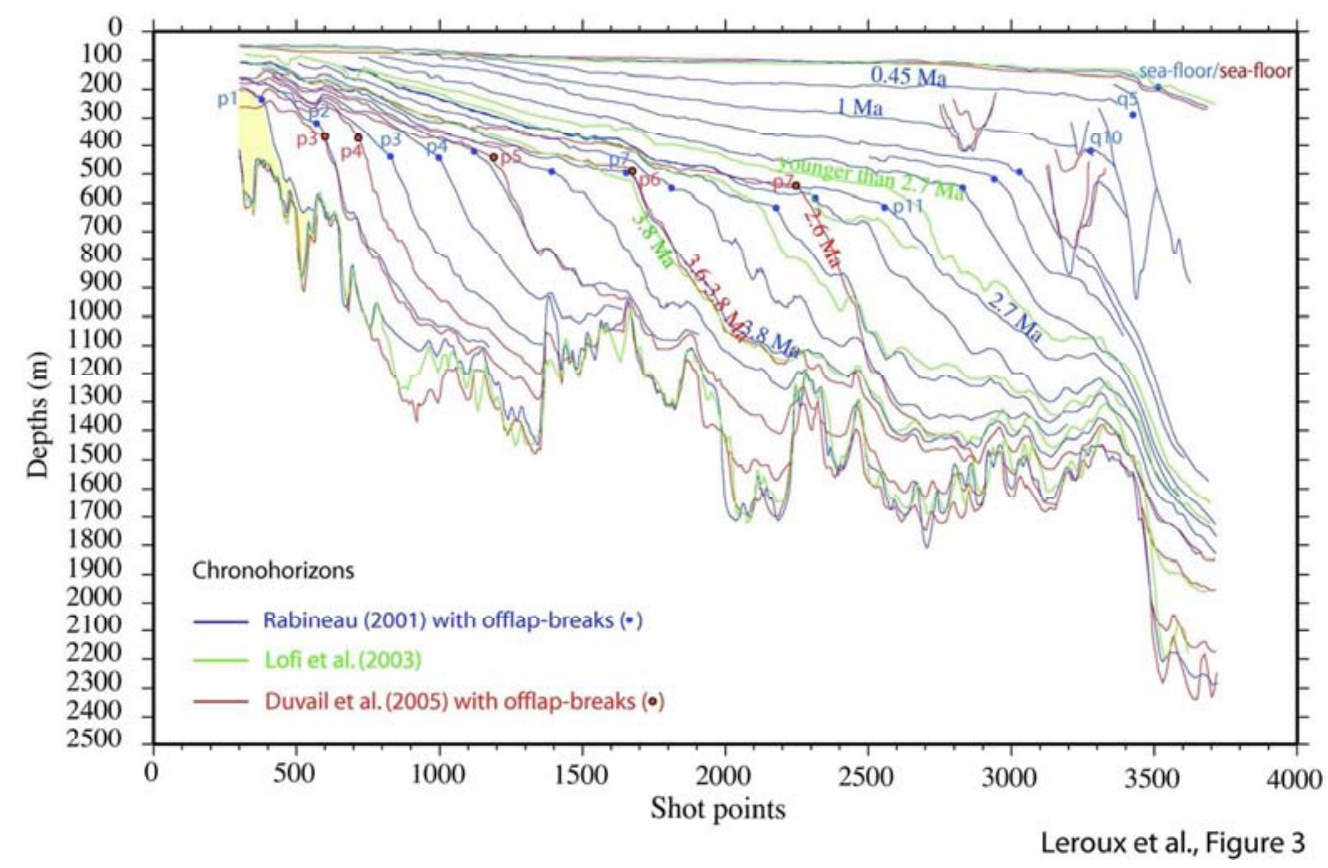

Figure 3. Synthesis of LRM18 seismic interpretations on the shelf of the Gulf of Lions by different authors. Interpretation from Rabineau (2001) in blue; interpretation from Lofi (2002) and Lofi et al. (2003) in green; interpretation from Duvail et al. (2005) and Duvail (2008) in red. The interpreted chronostratigraphic markers have been digitalized, time-depth converted and superimposed on the same vertical section with respective age estimates.

$118 \times 77 \mathrm{~mm}(300 \times 300 \mathrm{DPI})$ 
FIGURE A: CONSTANT SUBSIDENCE RATE

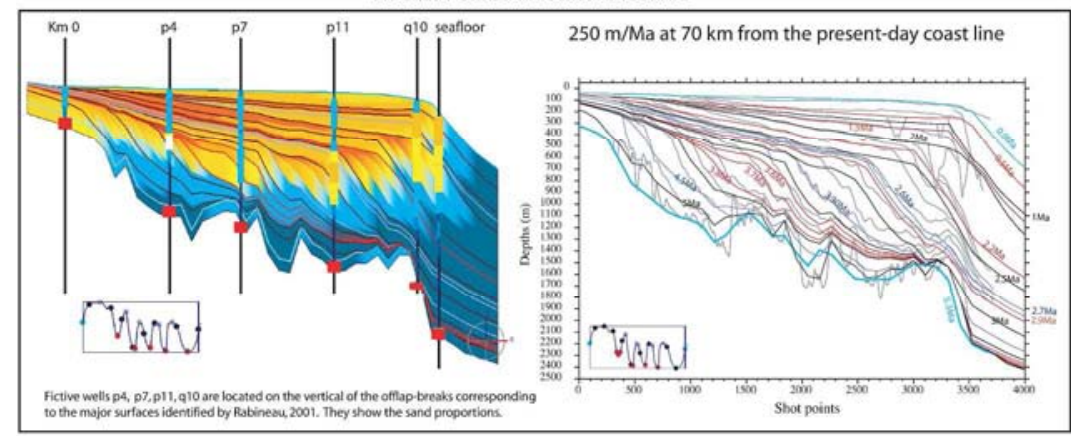

FIGURE B: VARYING SUBSIDENCE RATE

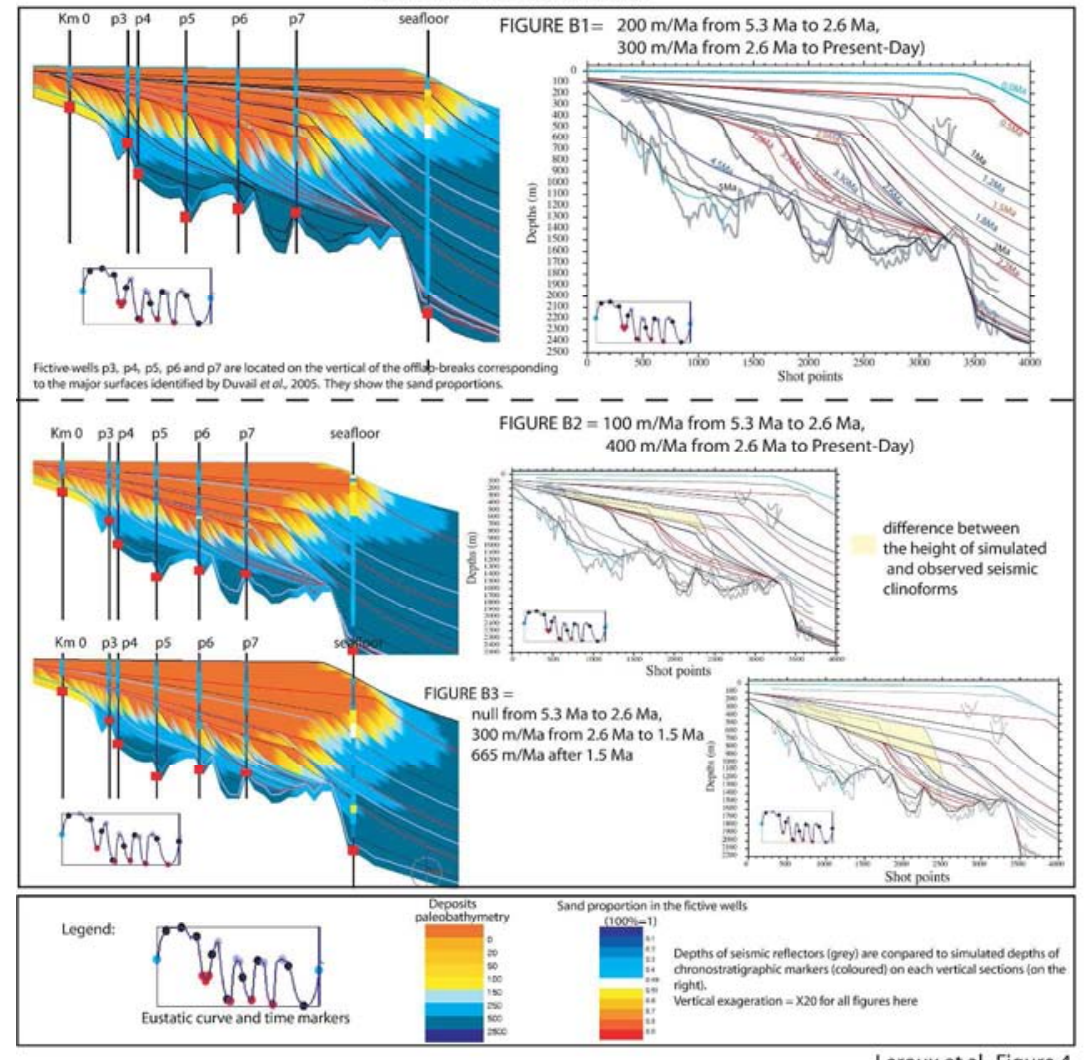

Leroux et al., Figure 4

Figure 4. Simulations testing subsidence rates with a 100000 years time-step (modified from Leroux, 2008).

Comparaison of LRM18 seismic profile interpretations (grey lines) with simulated geometries and deposits bathymetry predicted by Dionisos (thick coloured lines). The simulations are run with a third order sea-level curve (Haq et al., 1988). A) Simulation with a constant subsidence rate of $250 \mathrm{~m} / \mathrm{My}$ at $70 \mathrm{~km}$ from the coast, then B1), B2), B3) using increasing subsidence rates. Note that the change to overall progradingaggrading pattern occurs without any change in the subsidence rate. Note that we could not restitute the observations in B2 nor B3 when the increase of subsidence is too strong or with no subsidence between 5.3 $\mathrm{Ma}$ and 2.6 Ma. Note also that in both cases, the observed height for the Early Pliocene clinoforms could not be reproduced. Once the horizontal positions of the offlap-breaks along seismic profile have been adjusted, their simulated depths are too deep (see the highlighted yellow area on the right). In such a subsidence scenario, the accommodation which is created after $2.6 \mathrm{Ma}$ increases too much the topsets slopes of the clinoforms already deposited. Note on the fictive wells that sand is deposited at the shelf-break, whereas 
finer sediments (silt and shale) are deposited on the shelf and on the slope (with a downstream decreasing granulometry).

$293 \times 400 \mathrm{~mm}(300 \times 300 \mathrm{DPI})$ 


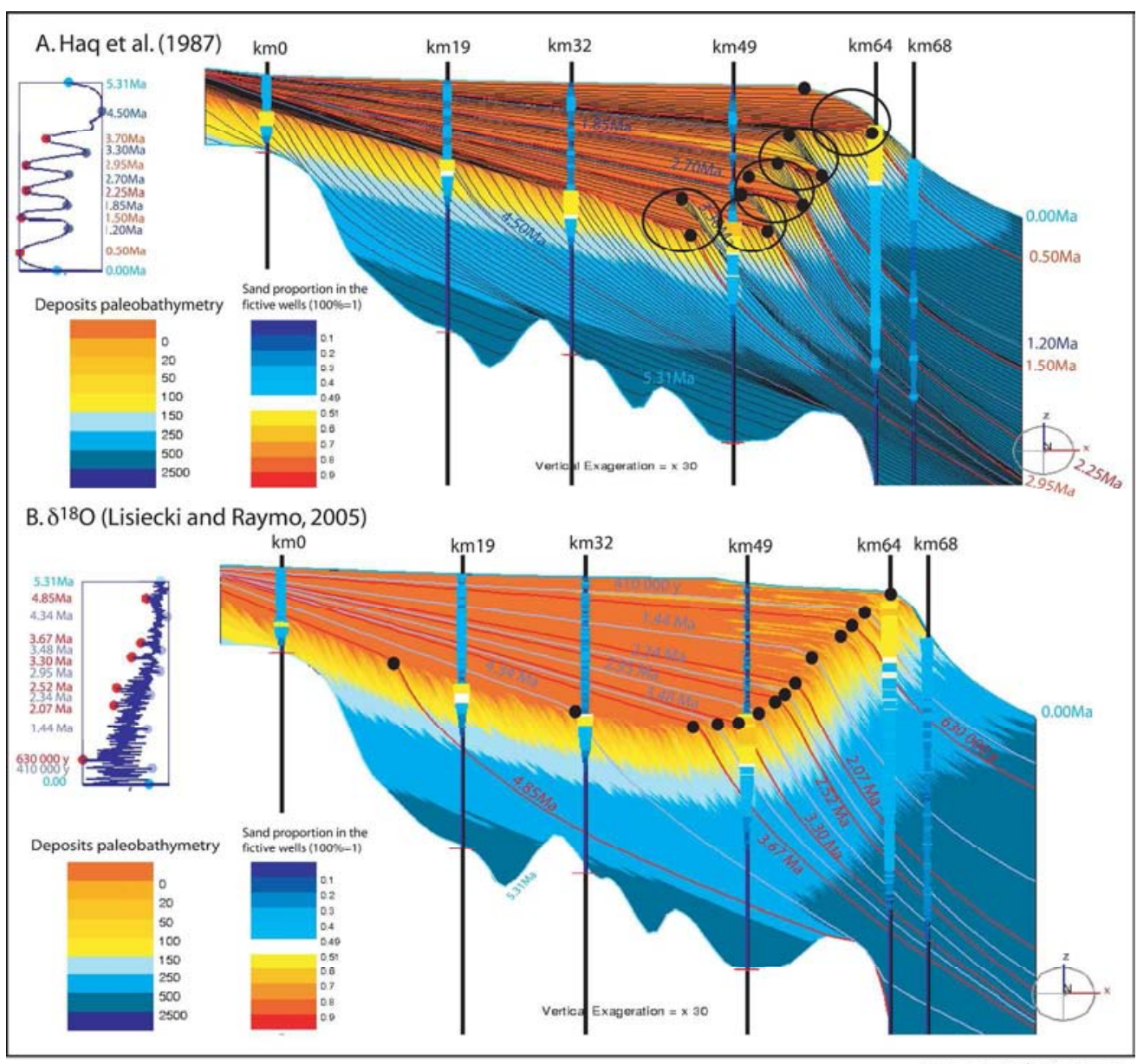

Leroux et al., Figure 5

Figure 5 - Simulations testing sea-level curves

Comparison of simulated geometries (modified from Leroux, 2008) using (A) Haq et al. (1987) sea-level curve and (B) a higher resolution sea-level curve resulting from $\partial 180$ data (Lisiecki and Raymo, 2005).

Simulations are running with a 10000 y time-step. All the others input parameters are identical in the both simulations (with constant $45 \mathrm{~km} 3 / \mathrm{My}$ sedimentary flux and $250 \mathrm{~m} / \mathrm{My}$ subsidence rate on the time interval). The chronomarkers correspond to the major sea-level falls (red) or to the Maximum Flooding Surface/MFS (blue). Black circles show offlap-break positions. 


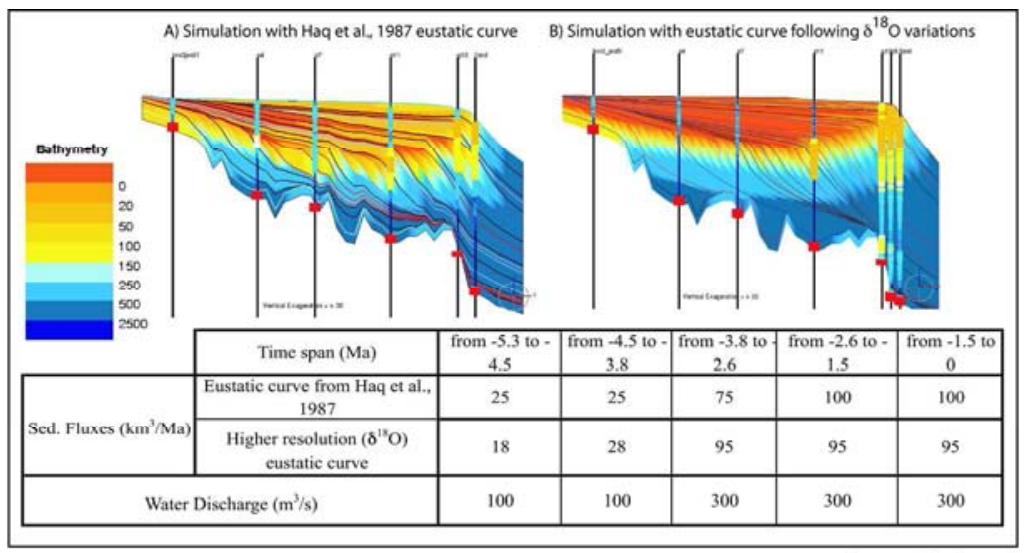

Leroux et al., Figure 6

Figure 6. Evolution of the required sediment fluxes in our modellings in the case of a constant PlioQuaternary subsidence rate. These fluxes result from 10000 years time step simulations with $(A)$ third order eustatic curve (Haq et al., 1988) and (B) (Lisiecki and Raymo, 2005) higher resolution eustatic curve. $195 \times 146 \mathrm{~mm}(300 \times 300$ DPI $)$ 